
Dorina ONESCU-TĂRBUJARU,

Nicole LEFTER

EFdeN Signature

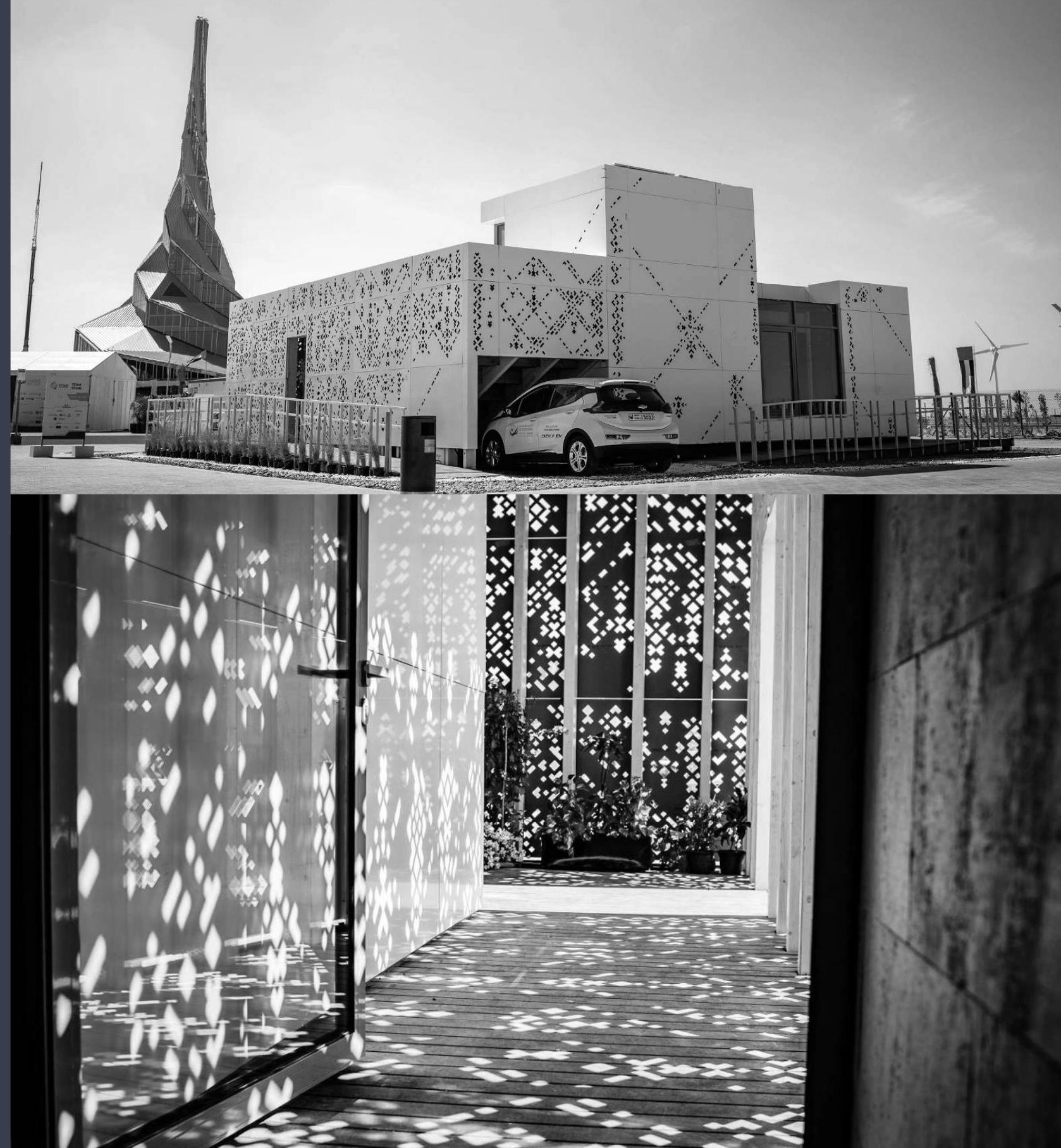




\section{EFdeN Signature}

Dorina ONESCU-TĂRBUJARU (1) Nicole LEFTER (2)

dorina@ot@yahoo.com ladriananicole@gmail.com

(1) Conf.Dr.Arhitect| Assoc.Prof.Dr.Architect, FAl*, UAUIM (2) Arhitect, EFDEN| (2) Architect, EFDEN

FAI*_Facultatea Arhitectură de Interior, UAUIM FAl* Faculty of Int

Departament Sinteza Proiectării de Arhitectură Facultatea de Arhitectură
Universitatea de Arhitectură și Urbanism lon Mincu
UAUIM Bucuresti Synthesis of Architectural Design Department (SP) Faculty of Architecture Ion Mincu University of Architecture and Urbanism

UAUIM Bucharest

\section{rezumat}

EFdeN Signature este casa ce a reprezentat România la competiția Solar Decathlon Middle East 2018, Dubai. Solar Decathlon este cea mai importantă competiție internațională de arhitectură și tehnologii integrate care a luat naștere în 2001 în Statele Unite ale Americii. Competiția constă în 10 probe (monitorizate sau jurizate), care provoacă echipele participante să proiecteze și să construiască o casă solară, eficientă energetic, astfel încurajând folosirea energiilor regenerabile și un mod de viață sustenabil.

cuvinte cheie

EFdeN, UAUIM, architecture school,

sustainability, Solar Decathlon, România abstract

EFdeN Signature is the house that represented Romania within the competition Solar Decathlon Middle East 2018 Dubai. Solar Decathlon is the most important internationa architecture and integrated technology competition, born in 2001 in United States. The competition consists in 10 tests (monitoring and jury judged), that challenge the participant teams to design and build a solar house, energy efficient, thus encouraging the use of the regenerative energies and a sustainable way of life.

\section{keywords}

EFdeN, UAUIM, architecture school,

sustainability, Solar Decathlon, Romania
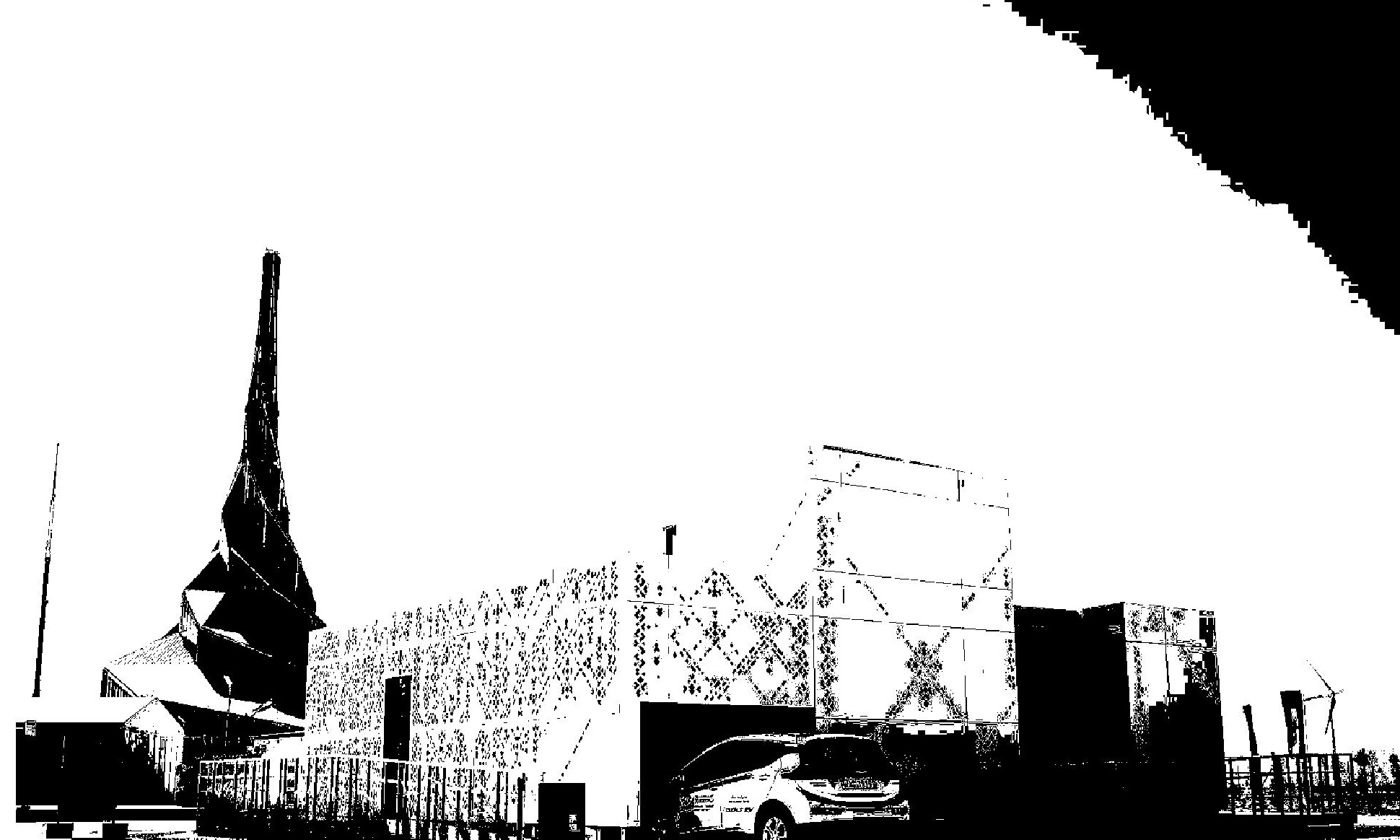
EFdeN Signature este casa ce a reprezentat România la competiția Solar Decathlon Middle East 2018, Dubai. Solar Decathlon este cea mai importantă competiție internațională de arhitectură și tehnologii integrate care a luat naștere în 2001 în Statele Unite ale Americii. Competiția constă în 10 probe (monitorizate sau jurizate), care provoacă echipele participante să proiecteze și să construiască o casă solară, eficientă energetic, astfel încurajând folosirea energiilor regenerabile și un mod de viață sustenabil.

Ediția din anul 2018, Solar Decathlon Middle East, o premieră în Orientul Mijlociu, a avut 15 echipe participante de pe 4 continente. Echipa României, formată la acel moment din 47 de studenti de la diverse universități din București, a participat cu casa EFdeN Signature și s-a întors acasă cu locul 4 mondial și 4 premii: premiul I la proba de comunicare, premiul II la inginerie și construcție, premiul II la condiții de confort și premiul III la proba de sustenabilitate. În plus, a mai obținut și locul II la votul publicului, locul IV la următoarele probe: funcționalitatea casei, eficiență energetică și transport electric.

Echipa EFdeN a făcut primii pași în anul 2012, fiind susținută de Universitatea Tehnică de Construcții București și Universitatea de Arhitectură și Urbanism "Ion Mincu" București. De atunci, peste 550 de studenți, absolvenți și masteranzi au făcut parte din echipa EFdeN, acumulând în total peste 350.000 de ore de voluntariat, timp în care au cercetat, proiectat și construit 2 case solare, eficiente energetic.
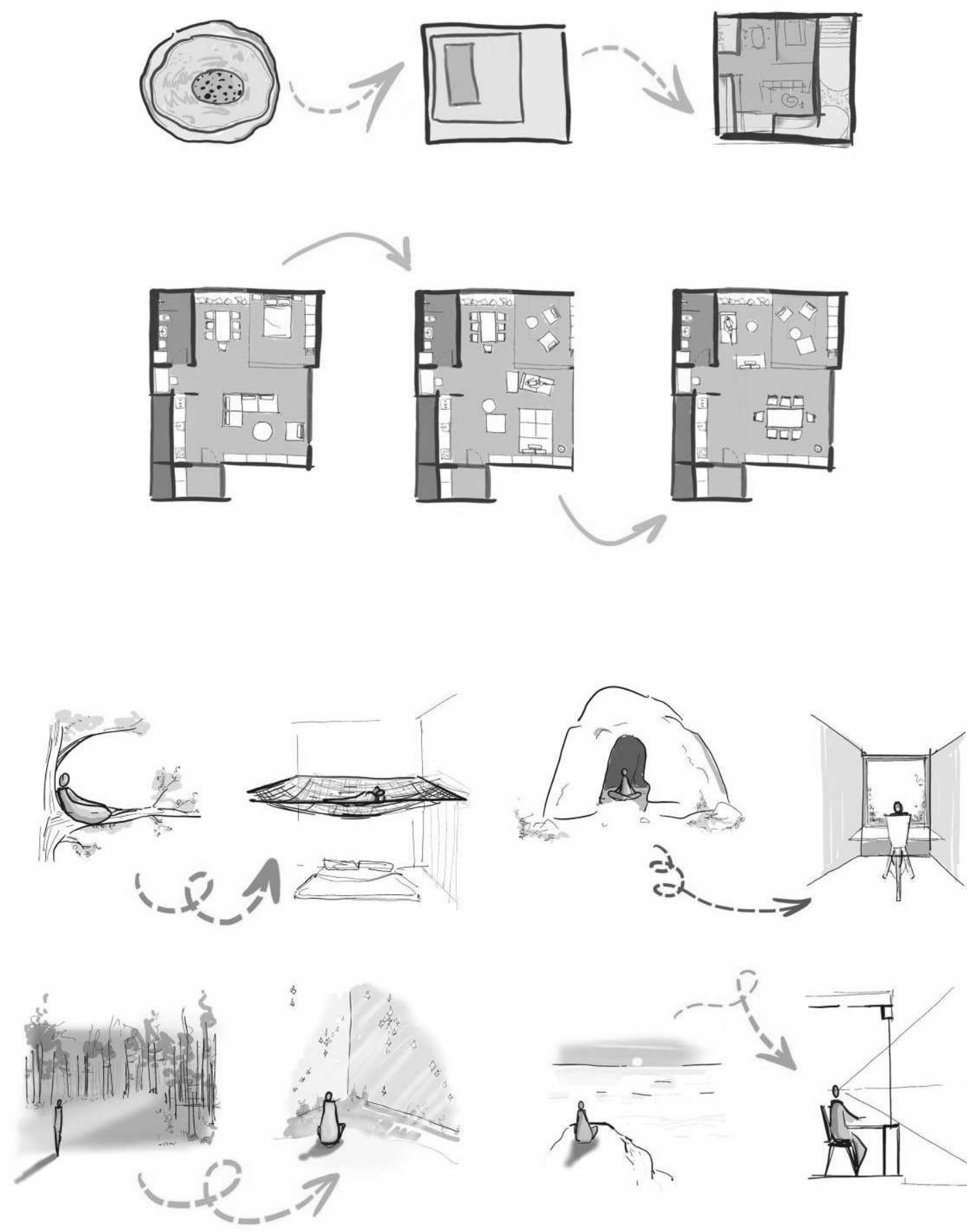


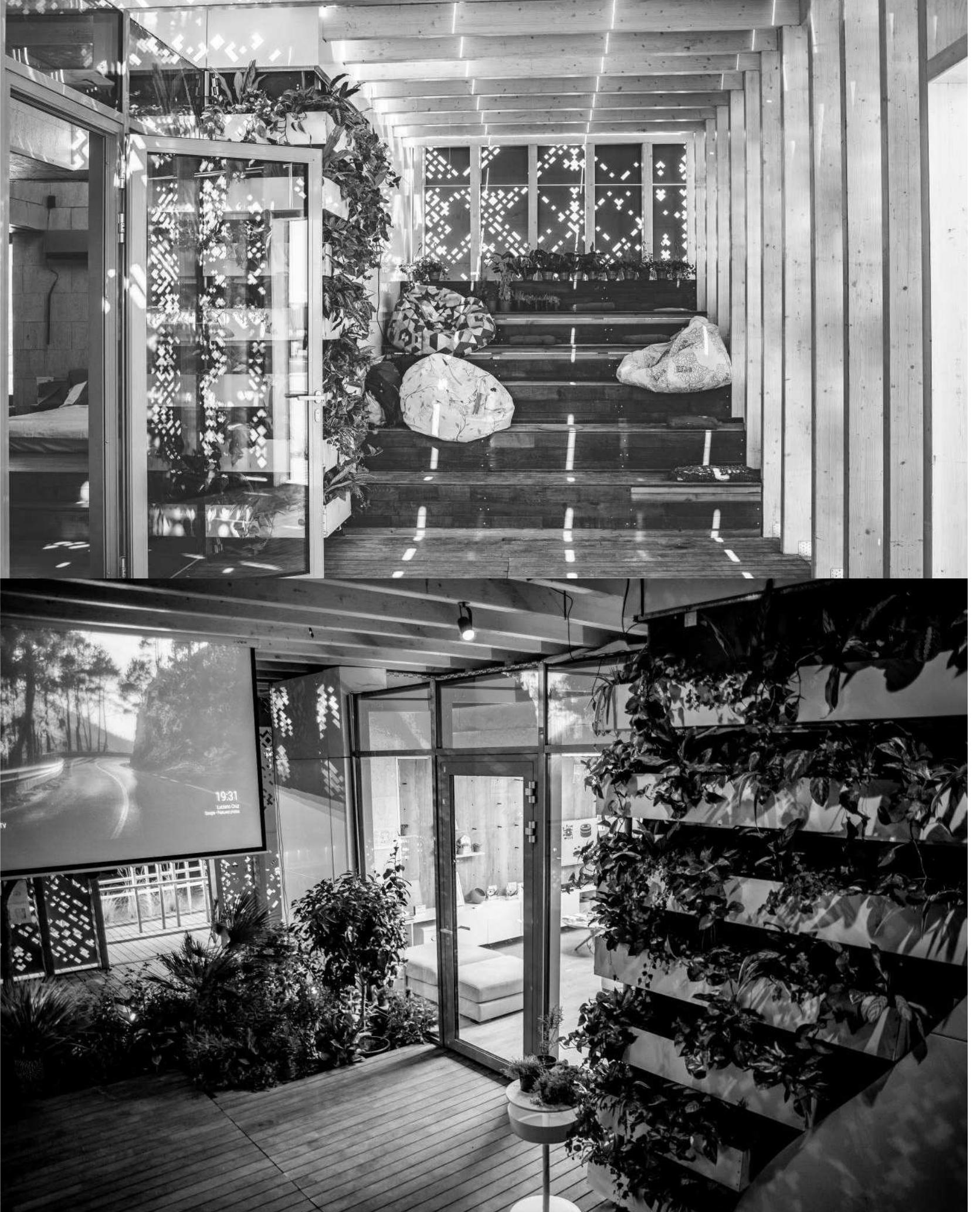

EFdeN Signature este o casă solară și eficientă energetic, proiectată pentru condițiile climatice din Orientul Mijlociu, cu posibilități de adaptare la climatul și contextul urban din România. Pentru a răspunde condițiilor climatice extreme din Orientul Mijlociu, precum radiație solară puternică și furtuni de nisip, casa e alcătuită din multiple învelișuri, asemenea unei celule, formând spații de tranziție. Fațada, care reprezintă și primul strat protector al casei, este o reinterpretare a strategiei pasive orientale de umbrire "mashrabiya”; iar perforațiile sunt inspirate din motive tradiționale românești. Aceasta filtrează radiația solară și protejează terasa de furtunile de nisip. Al doilea înveliș este reprezentat de terasa ce înconjoară casa pe două laturi și are rolul de a regla nivelul umidității prin prezența plantelor și a împiedica schimbul de energie termică între interior și exterior. Al treilea strat este reprezentat chiar de anvelopanta casei, bine termoizolată, ce menține parametrii de confort în interior.

Spațiul interior este foarte versatil, lucru datorat caracterului de "open-space", precum si a modularității obiectelor de mobilier. Toate spațiile sunt convertibile și permit o completă reconfigurare a funcțiunilor, potrivit nevoilor utilizatorului. Astfel interiorul casei permite transformarea zonei de dormit într-un spațiu dedicat hobby-urilor, extinderea living-ului (living room) sau a dining-ului (dining room) sau chiar schimbarea funcțiunilor între ele.

EFdeN Signature conectează omul cu natura prin conceptul biophilic design, natura fiind integrată prin suprafete vitrate mari, culori, texturi cu aspect natural, și forme organice, întregind o experiență senzorială pentru utilizator. Suprafeteele de sticlă stabilesc o legătură puternică între spațiul interior fluid cu spațiile plantate din terasă, unificându-le pe 
cele două. Lumina directă și cea difuză pun în evidență suprafețele și texturile din spațiul interior, iar lumina filtrată de perforațiile fațadei conferă dinamism și mimează razele de lumină ce trec prin coroana copacilor.

Numele casei EFdeN Signature este inspirat chiar din principiul de bază al sustenabilității și exprimă viziunea noastră prin faptul că semnătura sau amprenta fiecăruia asupra mediului trebuie să fie una cât mai redusă. Eficiența energetică este atinsă prin integrarea de strategii pasive și sisteme active automatizate, controlate prin intermediul unui asistent vocal.

Strategiile pasive au un rol semnificativ în reducerea necesarului de energie al casei, acestea reprezentând de fapt o orientare adecvată în funcție de punctele cardinale, poziționarea și dimensionarea ferestrelor pentru a face posibilă ventilarea naturală a spațiului interior (cross ventilation), alcătuirea anvelopantei, alegerea finisajelor exterioare, precum și umbrirea zonelor afectate de radiația solară puternică.
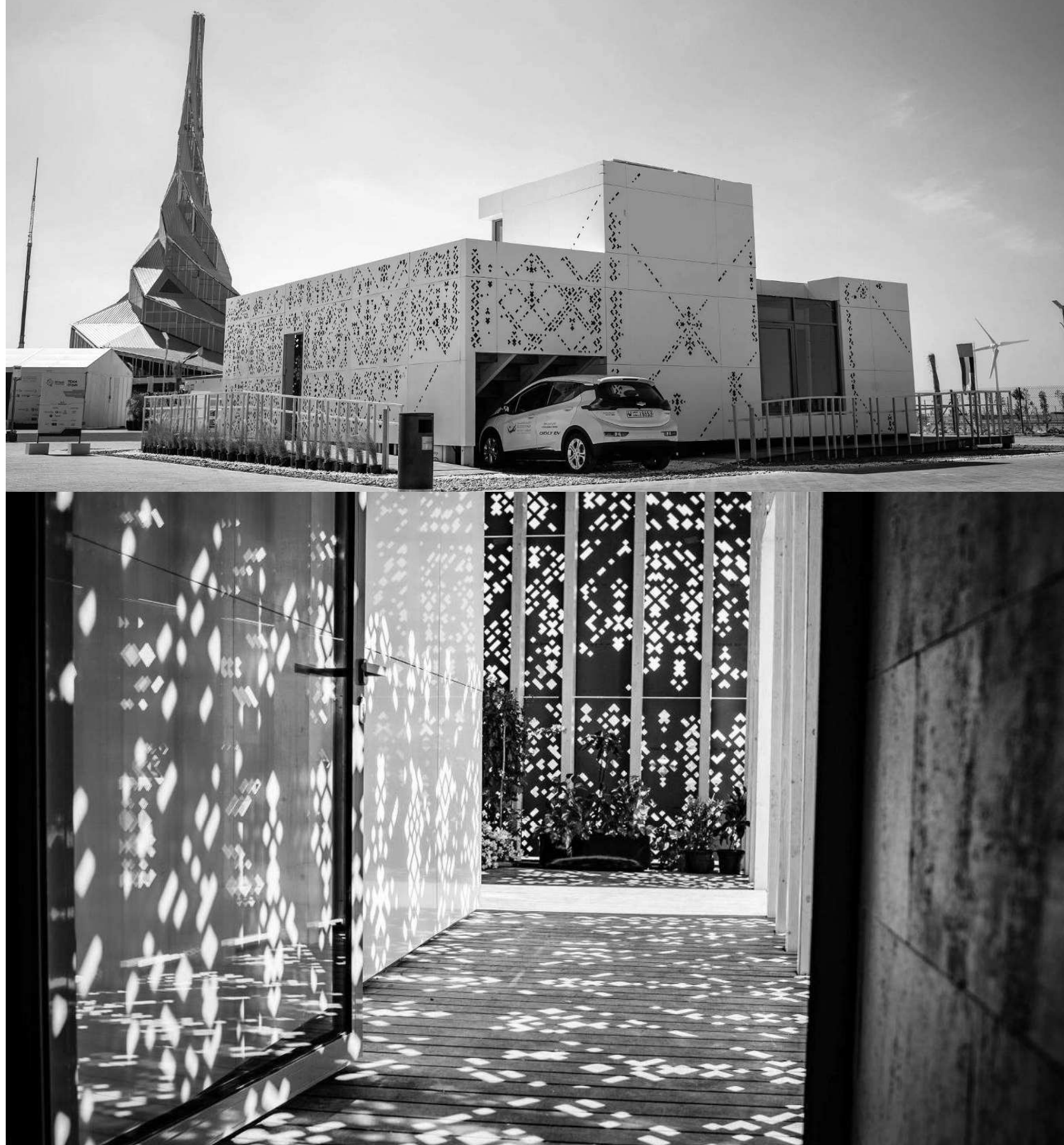


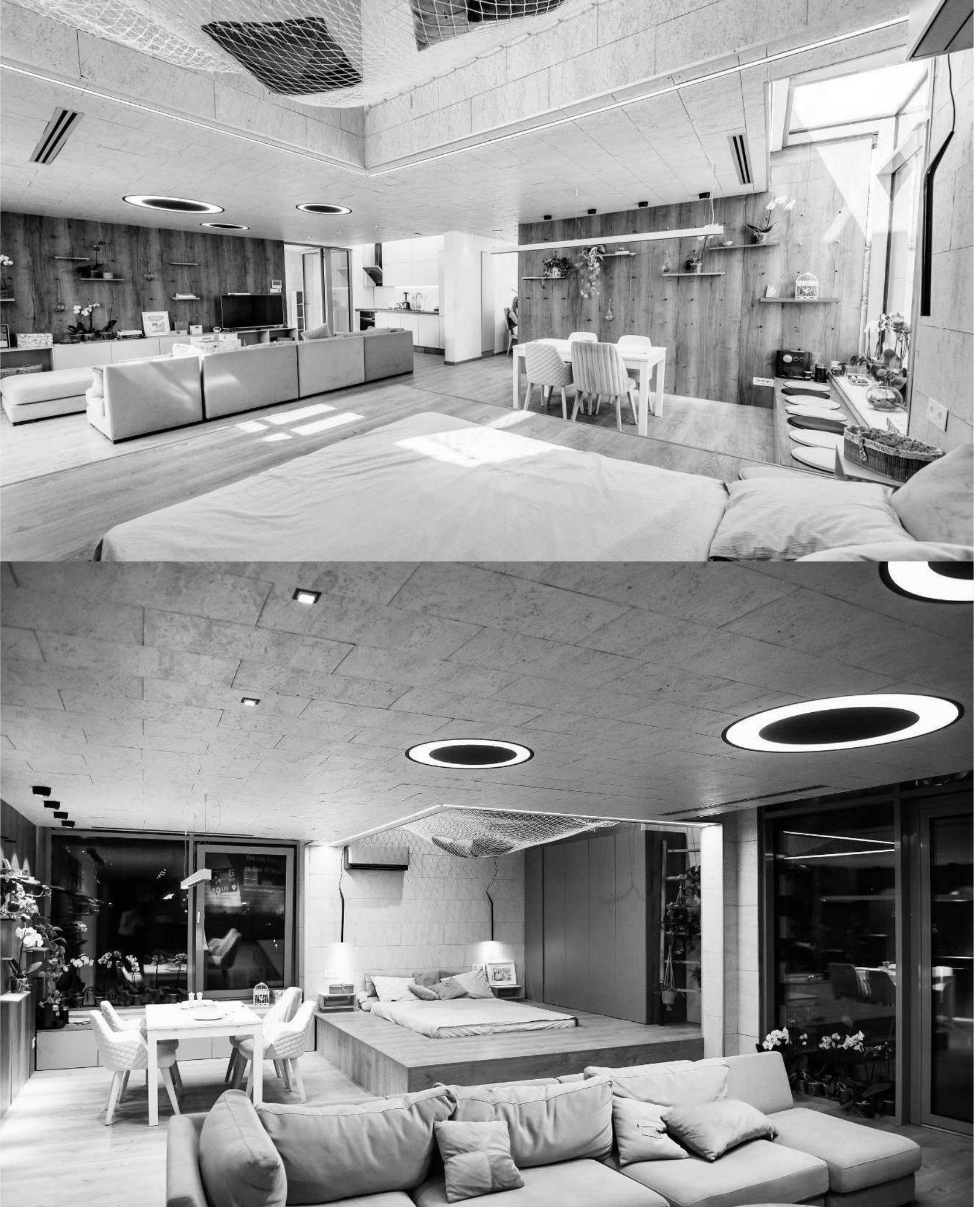

Principala strategie pasivă în EFdeN Signature este reprezentată întocmai de multiplele învelișuri create - fațada perforată, terasa plantată, spații de tranziție și anvelopanta bine termoizolată și etanșeizată. Stratul de vegetație de pe terasă ajută la filtrarea aerului și reduce temperatura acestuia în imediata apropiere. Windfang-ul, situat pe partea de sud, reprezintă intrarea principală a casei și are rolul de a facilita tranziția între condițiile climatice extreme din exterior și temperatura optimă din interiorul casei. Cele două turnuri aduc aminte la nivel formal de turnurile de vânt din Orientul Mijlociu și au un rol important în eficientizarea procesului de cross ventilation.

Casa este alimentată în totalitate din surse regenerabile de energie, 32 de panouri fotovoltaice, iar prepararea apei calde se realizează folosind un panou solar. Minimizarea consumului resurselor epuizabile, cum este apa, e posibilă datorită bateriilor si echipamentelor care optimizează consumul de apă, respectiv care tratează apa neagră și apa gri, cea din urmă putând fi ulterior folosită pentru irigații. Sistemul de iluminat este pe baza de LED, iar sistemul de ventilare și răcire, un sistem multi-split, a fost ales datorită eficienței pe mai multe planuri. Pe baza conceptului de daylight harvesting intensitatea iluminatul din interior se poate ajusta automat cu ajutorul unor senzori care înregistrează numărul de lucși produs de iluminatu natural.

În proiectarea casei, condițiile de confort au reprezentat un criteriu de bază, asigurând utilizatorului un mediu sănătos, controlat si adaptabil în funcție de necesități. 
Parametrii monitorizați sunt temperatura, umiditatea, nivelul de CO2, nivelul de zgomot și iluminatul.

Zgomotul produs de echipamentele tehnice, dar și zgomotul specific mediului urban ce pătrunde prin anvelopanta casei, au fost reduse pentru asigurarea confortului acustic din casă prin introducerea de straturi fonoabsorbante în interiorul pereților (vată minerală), dar și de finisajul interior, plută decorativă.

Provocările echipei pe parcursul acestor 2 ani au fost proiectarea, execuția și strângerea fondurilor necesare construcției și transportării casei în Dubai în TIR-uri și pe mare. Totul a culminat cu perioada competiției, în care echipa s-a confruntat cu formalități vamale, asamblarea casei în doar 15 zile, inspectiile pentru fiecare etapă finalizată, testarea, monitorizarea și jurizarea casei și a întregii munci timp de 2 săptămâni, și dezasamblarea acesteia în final în doar 5 zile. Prototipul EFdeN Signature, construit în integralitate de studenți, are un impact pozitiv pe mai multe planuri: pregătirea viitorilor profesioniști pentru cerințele unei case solare, promovarea soluțiilor folosite în proiectarea caselor solare, până la aducerea la cunoștință despre importanța folosirii energiei din surse regenerabile. EFdeN Signature este un proiect realizat de o echipă interdisciplinară de studenți, susținută de cadre universitare și companii, și este modul prin care echipa își duce mai departe misiunea de a face România mai sustenabilă și de a promova un stil de viață axat pe grija față de mediu.

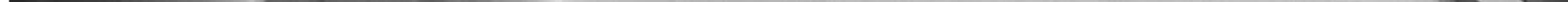


Imagini pentru publicare, de la autori / Images for publication, from the authors:

(in ordinea imaginilor articolului / in article's images order)

Fig.1-10 Casa EFdeN Signature / EFdeN Signature House

1 Imagine exterior, black\&white / Exterior image, black\&white 2 Schite proiect / Sketches of the project design

3, 6 Imagini terasa / Terace images

4 Imagine gradene / Gradens images

5 Imagine exterior / Exterior images

7, 8 Imagine interior - zi/noapte / Interior images - day/night

9 Zona birou / Office area

10 Imagine interior / Exterior Image

\section{Afiliere \& Multumiri / Acknowledgement}

EFdeN \& UAUIM București / Bucharest
EFdeN Signature is the house that represented Romania within the competition Solar Decathlon Middle East 2018, Dubai. Solar Decathlon is the most important international architecture and integrated technology competition, born in 2001 in United States. The competition consists in 10 tests (monitoring and jury judged), that challenge the participant teams to design and build a solar house, energy efficient, thus encouraging the use of the regenerative energies and a sustainable way of life.

The 2018 edition of Solar Decathlon Middle East, a premiere in the Middle East, had 15 participating teams from 4 continents. The Romanian team, formed at that time by 47 students from various universities in Bucharest, has participated with the EFdeN Signature house, and returned home with the 4th place in the world and 4 awards: 1st prize in the communication test, 2nd prize in engineering and construction, the second prize for comfort conditions and the third prize for the sustainability test. In addition, it has also obtained the second place in the public vote, the fourth place in the following tests: the functionality of the house, energy efficiency and electric transport.

EFdeN team took the first steps in 2012, being supported by the Universitatea Tehnică de Construcții București (Technical University of Constructions Bucharest) and Universitatea de Arhitectură și Urbanism "Ion Mincu" București ("Ion Mincu" University of Architecture and Urbanism, Bucharest). Since then, over 550 students, graduates and masters have been part of the EFdeN team, accumulating over 350,000 volunteer hours in total, during which they researched, designed and built 2 energy-efficient solar homes. 
EFdeN Signature is a solar and energy efficient home, designed for the climatic conditions in the Middle East, with possibilities for adaptation to the climate and urban context in Romania. In order to respond to the extreme climatic conditions in the Middle East, such as strong solar radiation and sandstorms, the house is made up of multiple shells, like a cell, forming transition spaces. The facade, which also represents the first protective layer of the house, is a reinterpretation of the passive oriental shading strategy, and the perforations are inspired by traditional Romanian motifs. It filters out the solar radiation and protects the terrace from sandstorms. The second cover is represented by the terrace that surrounds the house on two sides and has the role of regulating the level of humidity through the presence of plants and preventing the exchange of thermal energy between inside and outside. The third layer is represented by the envelope of the house, well insulated, which maintains the comfort parameters inside.

The interior space is very versatile, due to the openspace character, as well as the modularity of the furniture objects. All spaces are convertible and allow a complete reconfiguration of the functions, according to the needs of the user. Thus the interior of the house allows the sleeping area to be transformed into a space dedicated to hobbies, extending the living or dining room or even changing functions between them.

EFdeN Signature connects man with nature through the biophilic design concept, nature being integrated through large glass surfaces, colors, natural-looking textures, and organic forms, completing a sensory experience for the user. The glass surfaces establish a strong connection between the fluid interior space with the planted spaces on the terrace, unifying the two. The direct and diffused light underline the surfaces and textures of the interior space, and the light filtered by the perforations of the facade gives dynamism and mimics the rays of light passing through the crown-shape of the trees.

The name of the house, EFdeN Signature, is inspired by the basic principle of sustainability and expresses our vision that the signature or fingerprint of each one on the environment must be as small as possible. Energy efficiency is achieved by integrating passive strategies and automated active systems, controlled through a voice assistant.

Passive strategies have a significant role in reducing the energy requirements of the house, these in fact representing an adequate orientation according to the cardinal points, the positioning and sizing of the windows to make possible the natural ventilation of the interior space (cross ventilation), the composition of the tire, the choice of finishes, also the shading of areas affected by strong solar radiation.

The main passive strategy in EFdeN Signature is represented by the multiple layers created - the perforated façade, the planted terrace, the transition spaces, and the well-insulated and sealed envelope. The vegetation layer on the terrace helps to filter the air and reduces its temperature in the immediate vicinity. The windfang, located on the south side, represents the main entrance of the house and has the role of facilitating the transition between the extreme climatic conditions of the outside and the optimal temperature inside the house, playing an important role in streamlining the cross ventilation process.

The house is fully powered by renewable energy sources, 32 photovoltaic panels, and the preparation 
of hot water is carried out using a solar panel. We reduce the consumption of non renewable resources, such as water, by using fixtures and equipments that optimise the use of water, respectively treat black water and gray water, the latter can later be used for irrigation. The lighting system is LED-based, and the ventilation and cooling system, a multi-split system, has been chosen due to its efficiency on several planes. Based on the concept of daylight harvesting the intensity of the interior lighting can be adjusted automatically with the help of sensors that record the number of glosses produced by natural lighting.

In the design of the house, the comfort conditions have represented a basic criterion, ensuring the user a healthy environment, controlled and adaptable according to the needs.

The monitored parameters are temperature, humidity, CO2 level, noise level and lighting.

The noise produced by the technical equipment, but also the noise specific to the urban environment that is filtered-in through the envelope of the house, were reduced to ensure the acoustic comfort of the house by introducing sound-absorbing layers inside the walls (mineral wool), but also by the interior finish, decorative cork

The challenges of the team during these 2 years have been the design, execution and collection of the funds necessary for the construction and transport of the house in Dubai in TIRs and at sea. It all culminated with the competition period, in which the team faced customs formalities, assembling the house in just 15 days, inspections for each completed stage, testing, monitoring and judging the house and the whole work for 2 weeks and finally disassembling it in just 5 days. The EFdeN Signature prototype, built entirely by students, has a positive impact on several levels: preparing future professionals for the requirements of a solar house, promoting the solutions used in the design of solar homes, until they raise awareness about the importance of using energy from renewable sources. EFdeN Signature is a project carried out by an interdisciplinary team of students, supported by university staff and companies, and is the way in which the team carries on its mission to make Romania more sustainable and to promote a lifestyle focused on caring for environment. 
Lectură suplimentară \& Referințe / Further readings \& References

EFdeN. (2019). EfdeN. https://efden.org

UAUIM. (2019). UAUIM. http://uauim.ro

\section{Citare articol curent / Citation}

(Ro)

EFdeN, Onescu-Tărbujaru D., Lefter N. (2021). EFdeN Signature.

în Teoria proiectului de arhitectură. Idei construite. SP FA

UAUIM. EUIM - Editura Universitară Ion Mincu, București.

(En)

EFdeN, Onescu-Tărbujaru D., Lefter N. (2021). EFdeN Signature.

in Architectural design theory. Built ideas. SP FA UAUIM. EUIM -

Ion Mincu University Publishing House, Bucharest. 


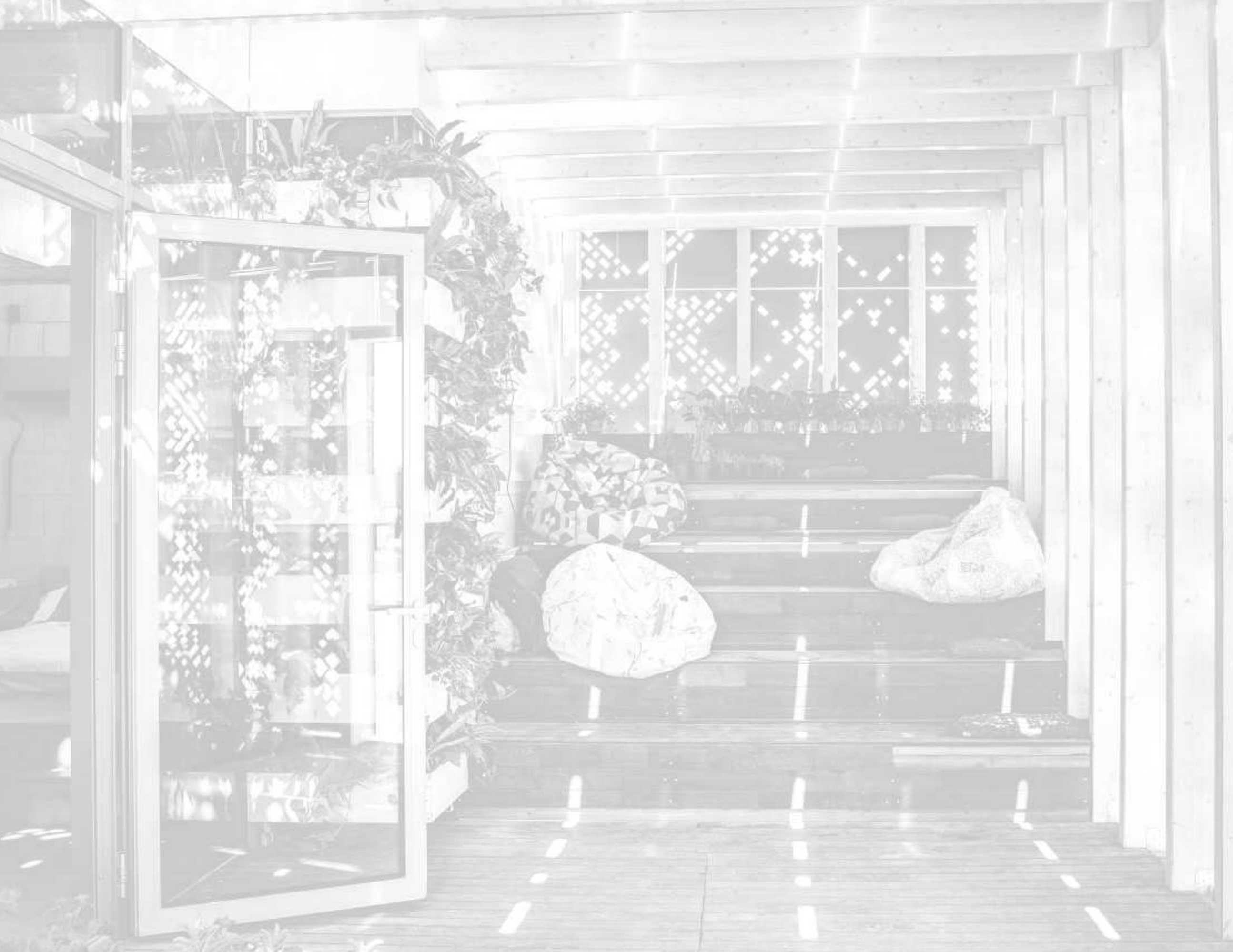



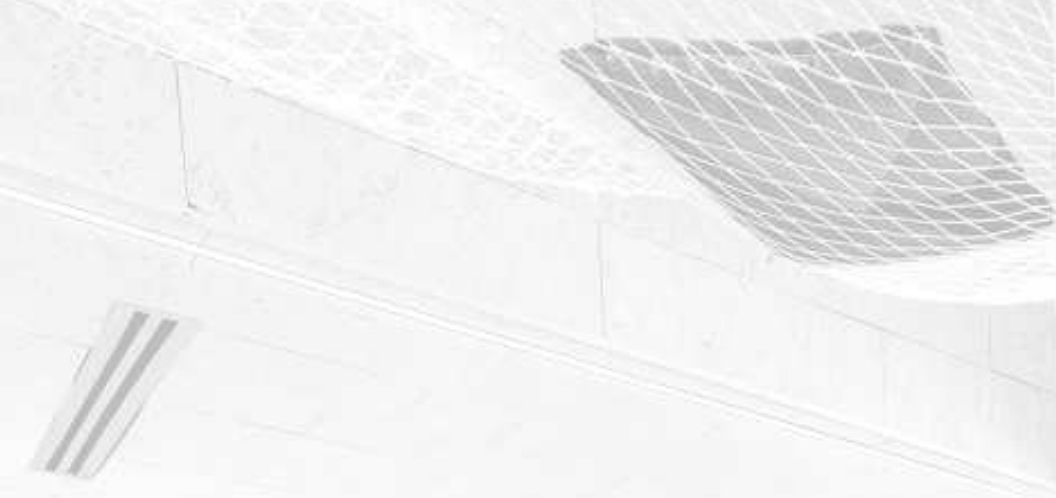

$x+4-1=2$ 